research worker in the general field of solar spectroscopy that St. John will be remembered. Among the problems that he worked at we may mention the gravitational displacement to the red of lines in the solar spectrum in accordance with the general theory of relativity. Closely allied with this was the study of systematic convection currents in the solar atmosphere invoked by St. John to account for anomalies in the observed Einstein effect. A full discussion of the Evershed effect in different levels in the sun's atmosphere in the immediate neighbourhood of sunspots was one of St. John's methods of analysing the layers in which the various Fraunhofer lines originated.

St. John's wide and exact knowledge of the solar spectrum in all its variants made of him a natural leader for the team recently engaged in the revision of Rowland's Preliminary Table of Solar WaveLengths, for St. John had been elected in 1922 president of the Commission on Standard WaveLengths and Tables of Solar Spectra of the International Astronomical Union. Later, when several of the solar commissions were combined into onethe Commission on Solar Physics-St. John was appointed its president, and he only gave up his active work for the Union a few months ago on account of failing health. He will be greatly missed. at the coming meeting of the Union. St. John was also a member of the Commission on Solar and Terrestrial Relationships working under the International Council of Scientific Unions. He was elected an associate of the Royal Astronomical Society in 1917.

\section{Mr. J. T. Cunningham}

OF Joseph Thomas Cunningham, whose death occurred suddenly in London on June 5, at seventysix years of age, it can with truth be said that he, more perhaps than most, through fair weather and through foul, preserved his youthful keenness and eagerness for biological research to the very end of a long life.

Born in London and educated at St. Olave's Grammar School, Southwark, Cunningham went up to Oxford, where his career was brilliant. He was Brackenbury science scholar of Balliol from 1878-81 and obtained first classes in mathematical modera. tions and in natural science. In zoology he was a pupil of Rolleston, who died in 1881. He was elected to a fellowship at University College, Oxford, in 1882, which he held until 1889.

After working for a time with Ray Lankester, Cunningham spent the winter of $1882-83$ at the Naples Zoological Station. His first publication (Q.J.M.S., Jan. 1882) was a review of recent work on karyokinesis. In 1883 he contributed to NATURE a description of the Naples Station, the occasion for which, he says, was the new Department of Comparative Physiology about to be opened there. In July of the same year there appeared two papers on his first researches, dealing with the nephridia of Patella and Aplysia.

Cunningham's career as a marine biologist commenced when, in 1884, after having been for a short time assistant to the professor of natural history at Edinburgh, he was appointed director of John Murray's floating marine laboratory (the Ark) at Granton, with Hugh Robert Mill as his colleague for hydrographical research. From 1887 until 1897 he was naturalist to the Marine Biological Association of the United Kingdom, being stationed at Plymouth until 1895 and then at Grimsby. He published during this time his monograph on the sole, which remains a standard work, and also his book on "Marketable Marine Fishes", in which much of his own research on the eggs and larvæ of fishes was summarised in convenient form. After serving for a period under the Cornwall County Council as lecturer on fishery subjects, he moved in 1902 to London, where he was engaged in teaching zoology, being from 1917 until 1926 lecturer at East London (Queen Mary) College.

Cunningham was a regular attendant at zoological meetings and frequently took part in the discussions. Although in later years theoretical aspects of biology were his chief interest, he seldom failed to direct attention to significant facts not generally known to his audience which had either come under his own observation or, although recorded, had been forgotten. When the present writer first knew him in 1892 his 'Lamarckian' outlook was already well established and he was always proud of the fact that he had received much help and encouragement in his study of the subject from Herbert Spencer. His own views were summarised in his book "Modern Biology : a Review of the Principal Phenomena of Animal Life in Relation to Modern Concepts and Theories" (1928), and his principal original contributions in "Hormones and Heredity" (1922), and "Sexual Dimorphism in the Animal Kingdom" (1900).

Cunningham was much interested in the experimental side of Mendelian work, as well as in experimental physiology, and always had in hand experiments of interest of his own. So recently as 1930 , when more than seventy, he went to Marajo, in the mouth of the Amazon, to study the function of the external filaments which develop during the breeding season on the pelvic limbs of the male lepidosiren; there he satisfied himself that the observations he was able to make confirmed a view he had previously expressed, that these filaments emitted oxygen to the eggs and larvæ, which develop and grow in the almost oxygen-destitute water in a burrow in the swamp.

E. J.A.

\section{Mr. H. W. Clinton-Baker}

THE death on April 19, at the age of seventy years, after a few days' illness, of Mr. H. W. Clinton-Baker, the Squire of Bayfordbury, removes a well-known Hertfordshire arboriculturist. Mr. Clinton-Baker will be best remembered for his keen interest in conifers, which he had made the hobby of a lifetime. $\mathrm{He}$ became the owner of the Bayfordbury estates in 1903 on the death of his father.

Mr. Baker's love for trees was no doubt inherited from his grandfather, Mr. William Robert Baker, who commenced the famous Bayfordbury pinetum in 1837. The Bayfordbury cedars, planted in 1765 by 
an ancestor, Sir William Baker, to commemorate the building of the house, are still among the finest in Great Britain. The pinetum, which at one time contained the best collection of conifers in the country, was considerably enlarged by the late Squire, who from time to time made numerous additions to it. Just before the War he commenced the formation of a new pinetum at Bell's Wood on another part of the estate, which he had planted with conifers recently introduced from China and elsewhere.

Between 1909 and 1913, Mr. Baker's interest in conifers took a more definite shape, when he published three handsome quarto volumes of "Illustrations of Conifers" which contained 'close-up' photographs of all the hardy species in cultivation. The letterpress for the work was prepared by the late Prof. A. Henry and Mr. A. B. Jackson, two well-known authorities on the group. These volumes are a valuable contribution to the literature of conifers, and have been of considerable assistance in the identification of the species. A supplementary volume to the series was commenced some time ago, and will be issued shortly. It is deeply to be regretted that Mr. Baker did not live to see its completion.

\section{News and Views}

Iron and Steel

WHEN delivering the Christmas lectures at the Royal Institution in 1925 on "Old Trades and New Knowledge", Sir William Bragg took for the subject of one of his lectures the trade of the smith. One of the objects of this lecture was to show how science has been applied to one of the oldest arts, and what it has revealed. Somewhat the same subject, but under the more prosaic title of "Iron and Steel", and dealt with in a different manner, was taken by Sir William Larke for his Friday evening discourse at the Institution on March 22, and this address is reproduced as a supplement in our issue this week. Within an hour, Sir William reviewed the whole history of the manufacture of iron and steel, pointing out some of the outstanding landmarks, referring to some of the chief inventors and touching upon some of the great achievements rendered possible by the metallurgists.

SINCE iron and steel were first used some thousands of years ago, and since iron was as precious as the crown jewels, many unknown inventors all over the world have added their contributions to the art of iron making, but as Mr. Charles Schwab said, every invention of fundamental importance in the modern iron and steel industry is British in origin. Such names as Darby, Huntsman, Cort, Neilson and Bessemer are well known, and the rise of the iron industry in Great Britain may be regarded both as a cause and a result of the so-called Industrial Revolution. Since the Norman Conquest, said Sir William, there may be said to have been three main phases of industrial development. The first extended to the beginning of the eighteenth century, when power was obtained from animals and men, the second lasted nearly a century and a half and may be described as the age of Iron and Coal, while the third phase, that of the development of metallurgy and alloy steels, has only lasted a quarter of a century, and we may be said to be at the beginning of a new era. Iron manufacture has profoundly influenced the standard of life in the past, and its effect on our social organisation is likely to continue to increase.

\section{Dr. Irving Langmuir, For.Mem.R.S.}

THE many friends of Dr. Irving Langmuir will note with pleasure that he has just been elected a foreign member of the Royal Society. It will be remembered (see Nature, p. 768, Nov. 19, 1932) that he was awarded the Nobel Prize for Chemistry in 1932. In referring to this award, it was pointed out that it is to Irving Langmuir that we owe the conception of the orientated monolayer as the state of material at phase boundaries. A clear and simple interpretation was found for many of the phenomena occurring at interfaces, and new light was thrown on such varied subjects as thermionics, heterogeneous catalysis and surface tension. More recently, Langmuir has been investigating the stability of oil lenses on water as determined by the nature of the monolayer of the interface, a problem with many biological implications. In addition, as the late Sir William Hardy first observed, the orientated monolayer on a metal surface plays an important function in lubrication. During the last two years, Langmuir has also made the important discovery that these layers are destroyed by the passage of a rubbing surface, but if the film be made thick enough, self-repair is effected. Finally, with his co-workers, Langmuir has been investigating the conditions of mobility of substances adsorbed in monolayers on metal substrates, one of the factors to be considered when the rates of catalytic actions are under review.

\section{Prof. Max Weber, For.Mem.R.S.}

The election of Prof. Max Carl Wilhelm Weber as a foreign member of the Royal Society gives welldeserved recognition to one whose influence on biological science is of outstanding importance. After earlier work on Crustacea, Prof. Weber soon entered upon his studies of fish, which were eventually to bring him into the front rank of ichthyologists of the day. His contributions to our knowledge of fish fauna have been very great and resulted from his personal travels into the far north, South Africa and the East Indian Archipelago. The fruits of his researches culminated in his comprehensive joint 